\title{
Sorghum (Sorghum bicolor) Pellet Production and Characterization
}

\author{
Izabelle Rodrigues Ferreira ${ }^{1}$ (i), Rosimeire dos Santos ${ }^{1}$, Renato Castro ${ }^{2}$ (1), \\ Angélica de Cássia Oliveira Carneiro ${ }^{3}$, Ana Flávia Castro ${ }^{2}$ (i), \\ Cynthia Patricia de Sousa Santos ${ }^{1}$ (1), Sarah Esther de Lima Costa ${ }^{1}$ (D), \\ Krisnara Mairinck ${ }^{2}$ (1)
}

\author{
${ }^{1}$ Universidade Federal do Rio Grande do Norte - UFRN, Macaíba/RN, Brasil \\ ${ }^{2}$ Universidade Federal de São Joao del-Rei - UFSJ, Sete Lagoas/MG, Brasil \\ ${ }^{3}$ Universidade Federal de Viçosa - UFV, Viçosa/MG, Brasil
}

\begin{abstract}
Pelletization is a technique used to compact biomass, generating a granulated material called pellets, with high energy density. The objectives of this work were to produce pellets made from Sorghum (Sorghum bicolor) residuals and to evaluate its quality. Firstly, the residuals were characterized, followed by the production of the pellets. An experimental framework was adopted, entirely randomized with three treatments: T1 $-100 \%$ Sorghum, T2 - Sorghum + addition of wheat starch, and T3 - Sorghum with the addition of steam. There was also a comparison of the properties of the pellets with values determined by the European standard. It was concluded that Sorghum biomass (Sorghum bicolor) residuals are viable for pellet production; products obtained were homogenous and easy to handle; the treatment $\mathrm{T} 1$ presented the best results for pellet production; all treatments produced pellets within the specifications of the EN 14961-6 (DIN, 2012) standard for non-wood pellets.
\end{abstract}

Keywords: pelletization; energy potential; biomass. 


\section{INTRODUCTION}

The worldwide energy production chain is dependent on petroleum and mineral carbon. These two sources have dominated the energy production supply since the industrial revolution, between the $18^{\text {th }}$ and $19^{\text {th }}$ centuries. Given this scenario, a series of alternatives for generating energy has been developed over the past years, addressing environmental, technological, political and social issues - one such being biomass (Abramowski \& Posorski, 2000).

Embrapa has researched Sorghum biomass, which presents energy potential similar to sugar cane, eucalyptus and elephant grass, for some years. The material can be used in thermoelectric plants as well as in industries that use boilers and generate energy for their own consumption.

Along these lines, Sorghum biomass is an alternative energy source that offers producers a quick way to obtain biomass. The other two major sources - sugar cane and eucalyptus - require from up to two to eight years, respectively, to mature for cutting and burning, while sorghum requires only four months to generate 40 to 50 tons per hectare (Emygdio et al., 2013).

The difficulties of handling, transporting, storing and using biomass in its original form are well-known. These difficulties arise from the high moisture content, irregular size and shape, and low density. The process of densification for the production of pellets and briquettes relies on high temperature and pressure, compacting the residuals, thus increasing their density, resulting in products of uniform size and shape, facilitating use and transport.

The briquetting or pelletization of agricultural and agroindustrial residuals consists of compacting the waste to obtain products with a higher density in $\mathrm{kg} / \mathrm{m}^{3}$ and energy density in $\mathrm{MJ} / \mathrm{m}^{3}$ than the original residuals. Consequently pelletizaiton, as a process of biomass densification, aims to reduce the volume of biomass, which subsequently decreases the transportation cost, facilitates its final use, and increases the quantity of energy per unit of volume (Dias et al., 2012; Carvalho et al. 2013).

Given this scenario, the present study aimed to produce pellets from Sorghum (Sorghum bicolor) residuals under different treatments, and to evaluate their quality.

\section{MATERIAL AND METHODS}

The present study was developed in the Laboratory of Wood Paneling and Energy (LAPEM) of the Department of Forest Engineering at the Federal University of Viçosa (UFV), in the city of Viçosa, Minas Gerais state. Raw materials used were Sorghum (Sorghum bicolor) biomass residuals donated by LAPEM, comprised of leaves and stems obtained from fields planted in areas belonging to the Department of Zootechnology at UFV.

The material was first triturated in a Wiley type laboratory mill, using the $257 \mathrm{om}-52$ Standard. Then it was sieved using $n^{\circ} 16$ international sieve with screens of 40 mesh, and $n^{\circ} 16$ international sieve with screens of 60 mesh (American Society for Testing and Materials - ASTM, 1982), using the sieved portion from the 60 mesh, generating particles.

The Sorghum particles were used in three treatments, as follows: T1 - 100\% Sorghum, T2 - Sorghum + addition of wheat starch, and T3 - Sorghum with the addition of steam.

The moisture content of the particles was determined using 3 samples from each treatment with approximately $0.500 \mathrm{~g}$. These were placed in an Ohaus infrared moisture analyzing device, MB35 Halogen model, at a temperature of $105^{\circ} \mathrm{C}$. This device comprises a precision scale and a drying unit with a halogen lamp, which operates according to the thermogravimeteric principle, to dry the samples and measure the mass until it achieves a consistent value. The moisture level of the starch was also measured, using this same principle.

A verification of the structural chemical composition was carried out by determining the content of total extractives, performed in duplicate, according to the TAPPI 204 om-88 TAPPI (1996) standard. The content levels of insoluble lignin were determined in duplicate using the Klason method, modified according to the procedures proposed by Gomide \& Demuner (1986). The holocellulose (cellulose and hemicellulose) content level was obtained by adding the levels of the extractive and the lignin totals, decreased by 100 .

The Gross Calorific Value (GCV) was determined according to the ABNT NBR 8633 (ABNT, 1986), with the use of an adiabatic bomb calorimeter. To determine the Net Calorific Value (NCV), the following formula was used (1): 


$$
N C V=[N C V x(1-M)]-600 M
$$

Where: $N C V=N C V(\mathrm{kcal} / \mathrm{kg}) ; M=$ moisture in dry base (\%); $N C V=$ net calorific value $(\mathrm{kcal} / \mathrm{kg})$.

The immediate chemical composition was determined according to the procedures described in the ABNT NBR 8112 (ABNT, 1981) standard, using a kiln, to obtain the values of volatile materials, ash content and fixed carbon content.

The density in bulk $\left(\mathrm{kg} / \mathrm{m}^{3}\right)$ was obtained according to the EN 15103 (DIN, 2010) standard, which uses a 1L volume beaker, filled with the sample to be analyzed, after which the mass was weighed.

The total mass obtained was subtracted from the mass of the beaker and in this way the mass of the sample in $\mathrm{m}^{3}$ was obtained, according to formula (2):

$$
B D=M / V
$$

Where: $B D=$ density in bulk $\left(\mathrm{g} / \mathrm{m}^{3}\right) ; M=$ mass inserted in the beaker $(\mathrm{g}) ; V=$ volume of the beaker $\left(\mathrm{m}^{3}\right)$.

To produce the pellets, approximately $8 \mathrm{~kg}$ of Sorghum (Sorghum bicolor) biomass was used in each of the three treatments. In treatment T2, along with the Sorghum particles, $400 \mathrm{~g}$ of wheat starch were previously mixed with the particles to act as binder in the pelletization process.

In T3, steam was added during the feeding of the pelletizer, however the quantity was not measured.

For this purpose, a laboratory pelletizer press was used with a horizontal disc base. The dimensions of the compression chutes of the base are an internal entrance diameter of $7.0 \mathrm{~mm}$ and exit diameter of $6.3 \mathrm{~mm}$, and $30 \mathrm{~mm}$ length. The pelletization temperature varied from 99 to $112{ }^{\circ} \mathrm{C}$ and a roller rotational speed of $1500 \mathrm{rpm}$.

To evaluate the quality of the pellets, an analysis of the following was carried out: Gross Calorific Value (GCV), Net Calorific Value (NCV), Dimensions, Density in Bulk, Durability, Percentage of Fines, Hardness, Hygroscopic Moisture Balance and Energy Density.

The diameter $(\mathrm{mm})$ and length $(\mathrm{mm})$ were obtained following the EN 16127 (DIN, 2010) standard. For this, $60 \mathrm{~g}$ of pellets for each treatment were measured for all units.
The bulk density $\left(\mathrm{kg} / \mathrm{m}^{3}\right)$ was obtained according to the EN 15103 (DIN, 2010) standard. The compaction rate was calculated by dividing the density of the pellets in bulk and the density of the material in bulk.

The mechanical durability and the percentage of fines (particles smaller than $3.15 \mathrm{~mm}$ ) were determined using the Ligno-Tester, Holmen equipment, according to the standards in DIN EN 15210-1 (DIN, 2010) and the equipment instructions. The sample of pellets were ventilated through a jet of air that simulated the natural destruction of the pellets during handling and transport, in a layer formed as an inverted quadrangular pyramid.

To determine the percentage of the fines, was used airflow with air pressure of 30 thousands of bar (tbar) for $30 \mathrm{~s}$. Later, the samples without fines were submitted to another controlled flow of air (70 tbar) during $60 \mathrm{~s}$ to determine the mechanical durability.

The hardness or resistance to smashing was determined by a pellet diametral compression test run on a manual Amandus Kahl durometer with a scale of 0 to $100 \mathrm{~kg}$. A pellet was inserted into the durometer and a charge was applied in increasing increments until the sample broke. Then, a reading of the maximum charge of what a pellet could withstand before splitting was registered, in $\mathrm{kg}$.

The hygroscopic moisture balance (HMB) of the pellets was determined after the samples of the biomass were conditioned in a climate chamber at a temperature of $23{ }^{\circ} \mathrm{C}$ and moisture relative to the air at $65 \%$ until it reached a constant mass.

The Energy Density of the pellets was obtained through the multiplication of the Net Calorific Value (NCV) by the density of the pellets in bulk, presented in $\mathrm{MJ} / \mathrm{m}^{3}$.

The experiment was analyzed with the delimitation as entirely randomized with three treatments: T1 - 100\% Sorghum, T2 - Sorghum + addition of wheat starch, and T3 - Sorghum with the addition of steam.

The data were submitted to the Lilliefors test to test for normality and the Cochran test to test for the homogeneity of the variances. Next, a variance analysis was carried out using the $\mathrm{F}$ test, with the means compared to the Tukey test. A significance of $5 \%$ was always considered.

The statistical analysis was carried out using the STATISTICA 8.0 (STATSOFT, Inc., 2009) program. 


\section{RESULTS AND DISCUSSION}

The results for the moisture analysis, Net Calorific Value, Gross Calorific Value, immediate and structural chemical analyses of the material used for the production of the briquettes are presented in Table 1.

Table 2 presents the mean values for the properties of the pellets in function of the treatment, and in comparison with the European standard.

In relation to the Net Calorific Value (NCV) of the particles, there was no statistical difference in the treatments T1 and T3, while for the pellets produced with the addition of $2 \%$ starch, these obtained the lowest values, thus leading to the consideration of the relationship as inversely proportional to the moisture. According to Brand (2010), the moisture of the fuel

Table 1. Mean values for moisture, net calorific values, gross calorific values, immediate and structural chemical analysis of the material used for briquette production.

\begin{tabular}{|lcc|}
\multirow{2}{*}{ Property } & \multicolumn{2}{c}{ Biomass } \\
\cline { 2 - 3 } & Sorghum & Starch \\
\hline Moisture $_{\text {bu }}(\%)^{*}$ & $4,61 \mathrm{~b}$ & $7,7 \mathrm{a}$ \\
\hline Net Calorific Value $(\mathrm{kcal} / \mathrm{kg})^{*} 3605,31 \mathrm{a}$ & $3302,41 \mathrm{~b}$ \\
\hline Gross Calorific Value (kcal/kg) & $4525,0 \mathrm{a}$ & $4121,5 \mathrm{a}$ \\
\hline Volatels (\%) & $83 \mathrm{~b}$ & $98 \mathrm{a}$ \\
\hline Ashes (\%) & $3 \mathrm{a}$ & $1 \mathrm{a}$ \\
\hline Fixed Carbon (\%) & $14,45 \mathrm{a}$ & $1,89 \mathrm{~b}$ \\
\hline Lignin (\%) & 29,05 & - \\
\hline Holocellulose (\%) & 52,8 & - \\
\hline Extractives (\%) & 15,6 & - \\
\hline
\end{tabular}

Same letters between lines for the same variable do not differ significantly from the Tukey test $(\mathrm{p}=0.05)$. is the main element responsible for the reduction of its Net Calorific Value, as the drying stage is where the greatest energy consumption occurs, due to the evaporation of the water. The GCV of this biomass was intermediary and the moisture of the pellets increased, which contributed to the low NCV of the pellets in T2.

The Gross Calorific Value of the pellets presented higher values than the Net Calorific Values in all of the treatments.

According to Obernberger \& Thek (2010), the moisture of the raw material for the production of pellets must be between 8.0 and $12.0 \%$. This is due to the fact that when the moisture is found below this interval, the transfer of heat becomes difficult and consequently the plasticization of the lignin as well; and when it is above the interval, the diameter and the length are not stable.

Results showed that there was no significant difference in the Gross Calorific Value between the Sorghum and the starch used for the production of the pellets.

It was observed that the content of the volatile materials of the Starch were higher, differing statistically from the Sorghum. According to Carroll \& Finnan (2012), the volatile materials are important for the quick liberation of energy, given that the greater the volatile content, the greater the burn speed in the gas phase.

The ash content of the Sorghum was greater than that observed for the starch, since it was not expected that this variable would increase in the pellets with the addition of starch. Low ash content in the biomass had little direct influence on the process of pelletization.

Table 2. Mean values of pellet properties and comparison with values established by the standard EN 14961-6 (DIN, 2012).

\begin{tabular}{lcccc}
\multicolumn{1}{c}{ Property } & $\begin{array}{c}\text { T1 } \\
\text { (Sorghum) }\end{array}$ & $\begin{array}{c}\text { T2 } \\
\text { (Sorghum + Starch) }\end{array}$ & $\begin{array}{c}\text { T3 } \\
\text { (Sorghum + Steam) }\end{array}$ & Reference values $^{*}$ \\
\hline NCV $(\mathrm{kcal} / \mathrm{kg})$ & $3660,5 \mathrm{a}$ & $3302,4 \mathrm{~b}$ & $3638,2 \mathrm{a}$ & - \\
Diameter $(\mathrm{mm})$ & $5,9 \mathrm{~b}$ & $6,01 \mathrm{a}$ & $5,9 \mathrm{~b}$ & $6 \pm 1$ \\
Length $(\mathrm{mm})$ & $19,7 \mathrm{a}$ & $20,1 \mathrm{a}$ & $19,8 \mathrm{a}$ & $3,15 \mathrm{a} 40$ \\
\hline BD $\left(\mathrm{kg} / \mathrm{m}^{3}\right)$ & $735,1 \mathrm{a}$ & $705,2 \mathrm{~b}$ & $717,2 \mathrm{~b}$ & $\geq 600$ \\
MD $(\%)$ & $99,3 \mathrm{a}$ & $99,4 \mathrm{a}$ & $99,5 \mathrm{a}$ & $\geq 97,5$ \\
Fines $(\%)$ & $0,008 \mathrm{a}$ & $0,078 \mathrm{a}$ & $0,017 \mathrm{a}$ & $\leq 2$ \\
Hardness $(\mathrm{kg})$ & $16,8 \mathrm{~b}$ & $18,9 \mathrm{a}$ & $18,5 \mathrm{a}$ & - \\
NCV $(\%)$ & $11,9 \mathrm{a}$ & $11,2 \mathrm{a}$ & $11,7 \mathrm{a}$ & $\leq 12$ \\
\hline ED $(\mathrm{MJ} / \mathrm{kg})$ & $11.104 .793 \mathrm{a}$ & $10.815 .303 \mathrm{c}$ & $10.933 .076 \mathrm{~b}$ & - \\
\hline
\end{tabular}

Means followed by the same letter for the same property do not differ significantly for the Tukey test $(p=0.05 \%)$. NCV = net calorific value; $\mathrm{BD}$ = bulk density; $\mathrm{MD}$ = mechanical durability; $\mathrm{ED}$ = energy density. ${ }^{*}$ Pellets - EN 14961-6 (DIN, 2012) standard for nonwood. 
However, if the ash content becomes greater than $10 \%$, it will wear out the rollers and the base of the pelletizer, reducing the operational life span of the equipment (Obernberger \& Thek, 2010). Thus the two values are well accepted.

The fixed carbon content was higher, by $14 \%$, differing from the starch, most likely due to the structural chemical composition of this biomass. The fixed carbon followed an indirect relationship with the content of the volatiles, such that the greater the content of the volatiles, the less the content of the fixed carbon.

In this study the mean values found for the structural chemical composition of the Sorghum were: $29.5 \%$ for the lignin content, $52.8 \%$ for the holocellulose content, and $15.6 \%$ for the extractives content. From the point of view of energy, the biomass should count on higher lignin and extractives content, since these substances liberate larger quantities of energy when submitted to combustion.

The Gross Calorific Value (GCV) is one of the most important properties to characterize materials such as fuel (Demirbas, 2002; Gillespie et al., 2013). This property is important to optimize the quantity of biomass in the production of energy, along with the dimensioning of storage installations (Gillespie et al., 2013). In other words, the greater the GCV, the lower the quantity of material necessary to serve a particular energy demand.

$\mathrm{T} 2$ presented the greatest diameter values. With relation to the length, there was no difference between the treatments.

The diameter of the pellets is determined by the compression chutes of the pelletizer, and the length is determined by knives located below the base, such that the length does not surpass a maximum defined by the height of the knives. According to Narra et al. (2010), the dimension and form of the pellets must be homogenous for the best functioning of small-scale furnaces and automatic heating equipment. The standardization of the dimensions of the pellets helps when choosing and dimensioning the feeder installations of the furnaces (Obernberger \& Thek, 2010). The diameter and the length of the pellets are in accordance with the standard requirements.

In $\mathrm{T} 1$, results showed the greatest Density Values of the pellets; however, they did not differ statistically from T3. Notably, the greater the pellets' density in bulk, the greater the energy density and the mass transported or stored in a container, minimizing the storage and transportation costs (Obernberger \& Thek, 2010).

It was observed that the Density in Bulk was greater than $300 \mathrm{~kg} \cdot \mathrm{m}^{3}$ for all materials evaluated. According to Tumuluru et al. (2011), normally the density in bulk of the agricultural and grass residuals vary from 80 to $150 \mathrm{~kg} \cdot \mathrm{m}^{3}$, and the density in bulk of wood, in chips or 16 shavings, from 150 to $250 \mathrm{~kg} . \mathrm{m}^{3}$. Therefore, the values obtained are not compatible with the values found by Tumuluru et al. (2011). Despite the higher values, the Densities in Bulk of all the treatments of pellets are in accordance with the requirements of the DIN EN 14588 standard (DIN, 2011).

With relation to the mechanical durability, the three treatments presented statistically similar values, as well as the percentage for fines.

The mechanical durability is the main parameter used to describe the physical quality of densified solid biofuels such as pellets (Carroll \& Finnan, 2012). It was observed that all pellets reached the specifications of the standard, greater than $97.5 \%$.

In accordance with the DIN EN 14588 standard, fines are particles with dimensions less than $3.15 \mathrm{~mm}$, generated by the friction between the pellets. The presence of fines is undesirable, since if it is above the maximum value stipulated, they can cause explosions in the storage silos (Tumuluru et al., 2011), as well as create health risk.

Regarding this property, the pellets of all treatments met the specifications of the standards, less than 2 . Despite this, it was observed that, with the addition of starch, the value for this property was higher.

The hardness is not a standardized property for pellets. However, the test provides a quick measure of the mechanical resistance of the pellets and can help in adjusting the process. It can be used as a tool to direct its use, whether domestic or even automatic industrial ovens (Zamorano et al., 2011; Protásio et al., 2011). Protásio et al. (2011) affirm that this physical characteristic is of great importance, since it is directly related to the stability and integrity of the briquettes during the transportation from the factory to the end consumer.

The quality of the pellets can also be improved by the use of additives with adhesive properties to the 
raw material (Berghel al., 2013; Tarasov et al., 2013). The main additives in pellets are starch, corn or potato flour, as well as some vegetable oils (Obernberger \& Thek, 2010). According to Tarasov et al. (2013), the additives can influence the physical, mechanical and energetic properties of the pellets. Findings of the present study showed that the addition of starch and steam increased the hardness of the pellets, corroborating with these authors.

The hygroscopic moisture balance based on moisture did not differ statistically among the different treatments, except for the pellets produced with the addition of $2 \%$ starch (T2), which had a lower HMB.

Obernberger \& Thek (2010) cite that the capacity required for the transportation and storage is reduced with the increase in energy density. This is because the greater the pellets' density in bulk, the higher its Energy Density and the greater the mass transported or stored in a container or silo of fixed volume (Obernberger \& Thek, 2010; Carroll \& Finnan, 2012).

Pellets with greater energy density are desirable because on burning they liberate a greater quantity of energy per volumetric unit. Rather, the quantity of energy transported or stored in one single volume is increased when there are pellets with greater energy densities (Pereira et al., 2016).

In short, aside from some statistical exceptions, the pellets meet all specifications of the EN 14961-6 (DIN, 2012) standard for non-wood pellets.

\section{CONCLUSION}

Given the results and its analysis, it is possible to conclude that:

According to the parameters evaluated, the Sorghum biomass (Sorghum bicolor) is proved feasible for the production of pellets - the products obtained were homogenous and easily handled.

Based on the data in this study, the treatment T2, Sorghum $+2 \%$ of starch, had the highest humidity, lowest density in bulk, greatest production of fines, and low energy density, making it the least recommended for the production of pellets.

On the other hand, treatment T1, 100\% Sorghum, presented the best values in the analysis of Density in Bulk, fines and Energy Density, conferring that this treatment was evaluated as the best for the production of pellets.

\section{SUBMISSION STATUS}

Received: 4 oct., 2017

Accepted: 19 feb., 2018

\section{CORRESPONDENCE TO}

\section{Renato Castro}

Departamento de Engenharia Florestal, Universidade Federal de São João Del-Rei, Campus Sete Lagoas, Rua Sétimo Moreira Martins, Itapoã II, CEP 35702031, Sete Lagoas, MG, Brasil e-mail: renatocastro@ufsj.edu.br

\section{FINANCIAL SUPPORT}

CNPq, FAPEMIG.

\section{REFERENCES}

Abramowski, J., Posorski, R. Wind energy in developing countries. DEWI Magazine, 2000;16:46-53.

American Society for Testing and Materials - ASTM. Standard method for chemical analysis of charcoal. Philadelphia: ASTM; 1982.

Associação Brasileira de Normas Técnicas - ABNT. NBR 8112 - Análise química imediata do carvão vegetal. Rio de Janeiro: ABNT; 1981.

Associação Brasileira de Normas Técnicas - ABNT. NBR 8633 - Carvão vegetal - Determinação do poder calorífico. Rio de Janeiro: ABNT; 1986.

Berghel J, Frodeson S, Granstrom K, Renstrom R, Stahl $M$, Nordgren $\mathrm{D}$ et al. The effects of kraft lignin additives on wood fuel pellet quality, energy use and shelf life. Fuel Processing Technology 2013; 112: 64-69. http://dx.doi. org/10.1016/j.fuproc.2013.02.011.

Brand MA. Energia da biomassa florestal. Rio de Janeiro: Interciência; 2010. 114 p

Carroll JP, Finnan J. Physical and chemical properties of pellets from energy crops and cereal straws. Biosystems Engineering 2012; 112(2): 151-159. http://dx.doi. org/10.1016/j.biosystemseng.2012.03.012.

Carvalho AMML, Pereira BLC, Souza MM. Produção de pellets de madeira. In: Santos F, Colodette J, Queiroz JH. Bioenergia e Biorrefinaria - cana-de-açúcar e espécies florestais. 1. ed. Viçosa: UFV; 2013.

Demirbas A. Relationships between heating value and lignin, moisture, ash and extractive contents of biomass fuels. Energy. Exploration \& Exploitation 2002; 20(1): 105-111. http://dx.doi.org/10.1260/014459802760170420. 
Deutsches Institut Fur Normung - DIN. EN 15210-1 - Solid biofuels-Determination of mechanical durability of pellets and briquettes - Part 1: Pellets. Alemanha: DIN; 2010.

Deutsches Institut Fur Normung - DIN. EN 14588 Terminology, definitions and descriptions. Berlim: DIN; 2011.

Deutsches Institut Fur Normung - DIN. EN 14961-6 - Solid biofuels - Fuel specifications and classes - Part 6: Non-woody pellets for non-industrial use. Alemanha: DIN; 2012.

Dias JMS et al. Produção de briquetes e péletes a partir de resíduos agrícolas, agroindustriais e florestais. Brasília: Embrapa Agroenergia; 2012.

Emygdio BM, Rosa APSA, Teixeira CC. LVIII Reunião Técnica Anual de Milho e XLI Reunião Técnica Anual de Sorgo: indicações técnicas para o cultivo de milho e de sorgo no Rio Grande do Sul safras 2013/2014 e 2014/2015. Brasília: Embrapa; 2013.

Gillespie GD, Everard CD, Fagan CC, Mcdonnel KP. Prediction of quality parameters of biomass pellets from proximate and ultimate analysis. Fuel 2013; 111: 771-777. http://dx.doi.org/10.1016/j.fuel.2013.05.002.

Gomide JL, Demuner BJ. Determinação do teor de lignina em material lenhoso: Método Klason modificado. O Papel 1986; 47(8): 36-38.

Narra S, Tao Y, Glaser C, Gusovius HJ, Ay P. Increasing the calorific value of rye straw pellets with biogenous and fossil fuel additives. Energy \& Fuels 2010; 24(9): 5228-5234. http://dx.doi.org/10.1021/ef100823b.

Obernberger I, Thek G. The Pellet Handbook-The production and thermal utilisation of biomass pellets. New York: Earthscan; 2010.
Pereira BLC, Carneiro ADCO, Carvalho AMML, Vital BR, Oliveira AC, Canal WD. Influência da adição de lignina kraft nas propriedades de pellets de eucalipto. Floresta 2016; 46(2): 235-242. http://dx.doi.org/10.5380/ rf.v46i2.44936.

Protásio TP, Alves ICN, Trugilho PF, Silva VO, Baliza AER. Compactação de biomassa vegetal visando à produção de biocombustíveis sólidos. Pesquisa Florestal Brasileira 2011; 31(68): 273-283. http://dx.doi.org/10.4336/2011. pfb.31.68.273.

STATSOFT, Inc. STATISTICA (data analysis software system), version 8. Tulsa: Statsoft, Inc; 2009.

Tappi Technical Divisions and Committees - TAPPI. TAPPI test methods. Atlanta: Tappi Technical Divisions and Committees; 1996. 46 p.

Tarasov D, Shahi C, Leitch M. Effect of additives on wood pellet physical and thermal characteristics: a review. ISRN Forestry 2013; 2013: 6. http://dx.doi. org/10.1155/2013/876939.

Tumuluru JS, Wright CT, Hess JR, Kenney KL. A review of biomass densification systems to develop uniform feedstock commodities for bioenergy application. Biofuels, Bioproducts \& Biorefining 2011; 5(6): 683-707. http:// dx.doi.org/10.1002/bbb.324.

Zamorano M, Popov V, Rodríguez ML, García-Maraver A. A comparative study of quality properties of pelletized agricultural and forestry lopping residues. Renewable Energy 2011; 36(11): 3133-3140. http://dx.doi.org/10.1016/j. renene.2011.03.020. 